LA W RENCE LIVERMORE NATIONAL LABORATORY

Plutonium 239 Equivalency Calculations

J. Wen

July 7,2011 
This document was prepared as an account of work sponsored by an agency of the United States government. Neither the United States government nor Lawrence Livermore National Security, LLC, nor any of their employees makes any warranty, expressed or implied, or assumes any legal liability or responsibility for the accuracy, completeness, or usefulness of any information, apparatus, product, or process disclosed, or represents that its use would not infringe privately owned rights. Reference herein to any specific commercial product, process, or service by trade name, trademark, manufacturer, or otherwise does not necessarily constitute or imply its endorsement, recommendation, or favoring by the United States government or Lawrence Livermore National Security, LLC. The views and opinions of authors expressed herein do not necessarily state or reflect those of the United States government or Lawrence Livermore National Security, LLC, and shall not be used for advertising or product endorsement purposes.

This work performed under the auspices of the U.S. Department of Energy by Lawrence Livermore National Laboratory under Contract DE-AC52-07NA27344. 


\section{Plutonium 239 Equivalency Calculations}

\section{Engineering Reference Document ERD11-500002-AA}

Prepared by:

Josh Wen, TRED

Date

LLNL, Engineer

Concurred by:

Tony Ladran, DTED

Date

LLNL JASPER Engineering Lead

Approved by:

Randy Thomas, DTED

Date

LLNL JASPER Program Operations Manager 


\section{REVISION HISTORY}

\begin{tabular}{|c|c|c|c|}
\hline $\begin{array}{c}\text { Revision } \\
\text { Number }\end{array}$ & \multicolumn{1}{|c|}{ Description \& Reason for Change } & $\begin{array}{c}\text { Affected } \\
\text { Pages }\end{array}$ & Date \\
\hline AA & Initial version of document & All & $5 / 24 / 11$ \\
\hline & & & \\
\hline & & & \\
\hline & & & \\
\hline & & & \\
\hline
\end{tabular}

\section{Contents}

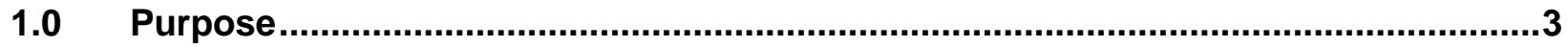

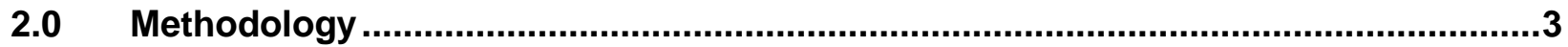

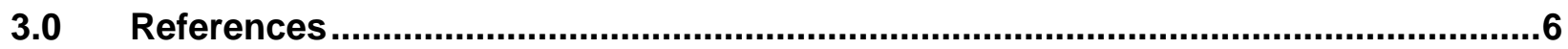

Plutonium 239 Equivalency (PuE) Calculation Datasheet ....................................................

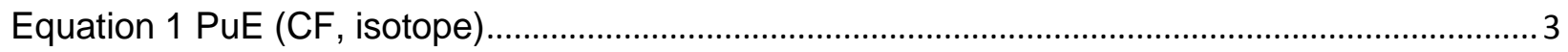

Equation $2 \mathrm{M}$,isotope .......................................................................................................

Equation 3 CF Isotope .................................................................................................... 4

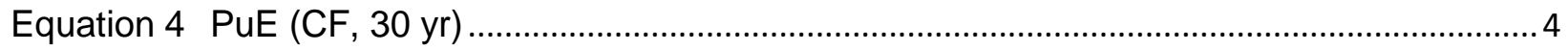

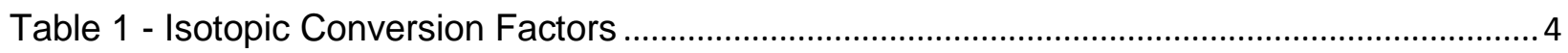

Table 2 - Typical 30-year-old Weapons Grade .........................................................................

Table 3 - 30-year-old Weapons Grade Conversion Factor ................................................................ 


\subsection{Purpose}

This document provides the basis for converting actual weapons grade plutonium mass to a plutonium equivalency (PuE) mass of Plutonium 239.

The conversion can be accomplished by performing calculations utilizing either:

1) Isotopic conversions factors $\left(\mathrm{CF}_{\text {isotope }}\right)$, or

2) 30-year-old weapons grade conversion factor $\left(\mathrm{CF}_{30}\right.$ yr $)$

Both of these methods are provided in this document.

\subsection{Methodology}

\subsection{Isotopic Conversion Factors}

Material mass and isotopic data are needed to calculate PuE using the isotopic conversion factors, which will provide the actual PuE value at the time of calculation.

PuE is the summation of the isotopic masses times their associated isotopic conversion factors for plutonium 239. [Equation 1]

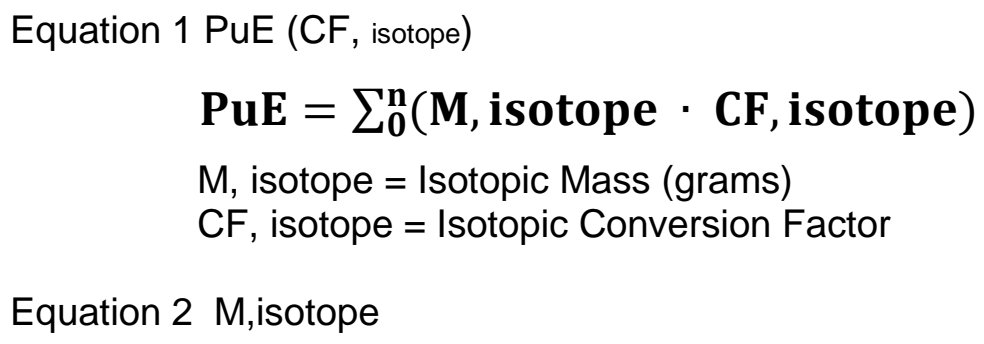

\section{$M$, isotope $=M$, total $\cdot$ Isotope weight $\%$}

$\mathrm{M}$, total = Plutonium mass

Isotopic conversion factors are calculated by a normalized equation, relative to Plutonium 239, of specific activity (SA) and cumulated dose inhalation affects based on 50-yr committed effective dose equivalent (CEDE). [Equation 3] 
Equation 3 CF Isotope

$$
\mathrm{CF}_{\text {isotope }}=\left(\frac{\mathrm{SA}_{\text {isotope }}}{\mathrm{SA}_{\mathrm{Pu} 239}}\right) \cdot\left(\frac{\mathrm{CEDE}_{\text {isotope }}}{\mathrm{CEDE}_{\mathrm{Pu} 239}}\right)
$$

The isotopic conversion factors for converting weapons grade plutonium to PuE are provided in Table-1.

Table 1 - Isotopic Conversion Factors

\begin{tabular}{|l|l|l|l|}
\hline Isotope & SA (Ci/g) & CEDE $(\mathbf{r e m} / \mathbf{C i})$ & $\mathbf{C F}_{\text {isotope }}$ \\
\hline Pu238 & $1.713 \mathrm{E}+01$ & $4.80 \mathrm{E}+08$ & $2.63 \mathrm{E}+02$ \\
\hline Pu239 & $6.133 \mathrm{E}-02$ & $5.10 \mathrm{E}+08$ & $1.00 \mathrm{E}+00$ \\
\hline Pu240 & $2.268 \mathrm{E}-01$ & $5.10 \mathrm{E}+08$ & $3.70 \mathrm{E}+00$ \\
\hline Pu241 & $1.031 \mathrm{E}+02$ & $1.00 \mathrm{E}+07$ & $3.30 \mathrm{E}+01$ \\
\hline Pu242 & $3.931 \mathrm{E}-03$ & $4.80 \mathrm{E}+08$ & $6.03 \mathrm{E}-02$ \\
\hline Am241 & $3.428 \mathrm{E}+00$ & $5.20 \mathrm{E}+08$ & $5.70 \mathrm{E}+01$ \\
\hline
\end{tabular}

The unit for specific activity $(\mathrm{SA})$ is curies per gram $(\mathrm{Ci} / \mathrm{g})$ and the isotopic SA values come from reference [1].

The cumulated dose inhalation effect values in units of rem/Ci are based on 50 -yr committed effective dose equivalent (CEDE). A person irradiated by gamma radiation outside the body will receive a dose only during the period of irradiation. However, following an intake by inhalation, some radionuclides persist in the body and irradiate the various tissues for many years. There are three groups CEDE data representing lengths of time of 0.5 (D), 50 (W) and 500 (Y) days, which are in reference [2]. The CEDE values in the $(\mathrm{W})$ group demonstrates the highest dose equivalent value; therefore they are used for the calculation.

\section{$2.2 \quad 30$-year-old Weapons Grade Conversion Factor}

To calculate PuE using the 30-year-old weapons grade conversion factor, the Pu element mass and knowledge that the age is less than 30 years since separation is needed (no isotopic data required), which will provide a conservative PuE value.

PuE is total elemental mass times 30 -year-old weapons grade conversion factor.

[Equation 4]

Equation 4 PuE (CF, $30 \mathrm{yr}$ )

$$
\text { PuE }=\left(\sum_{0}^{\mathrm{n}} \mathrm{M} \text {, isotope }\right) \cdot \mathrm{CF}, 30 \mathrm{yr}
$$

$\mathrm{CF}, 30 \mathrm{yr}=30$-year-old weapons grade conversion factor 
The conversion factor for 30 year-old weapons grade plutonium $\left(\mathrm{CF}_{30} \mathrm{yr}\right)$ is calculated using a typical isotopic composition and weight percentage of 30 -yr-old weapons grade plutonium values from Table 2 and isotopic conversions factors from Table 1 . The Table 2 values are from reference [3].

In using this calculation, the user must know that the material is less than 30 years since separation.

Table 2 - Typical 30-year-old Weapons Grade

\begin{tabular}{|c|c|}
\hline \multicolumn{2}{|c|}{ 30-year-old Weapons Grade Plutonium } \\
\hline Isotope & Weight \% \\
\hline Pu238 & 0.03 \\
\hline Pu239 & 93.26 \\
\hline Pu240 & 5.98 \\
\hline Pu241 & 0.14 \\
\hline Pu242 & 0.04 \\
\hline Am241 & 0.45 \\
\hline
\end{tabular}

$\mathrm{CF}_{30 \mathrm{yr}}=\mathbf{1 . 5 3 5}$ as calculated in Table 3.

Table 3 - 30-year-old Weapons Grade Conversion Factor

\begin{tabular}{|c|c|c|c|}
\hline Isotope & A. Weight \% & B. CF $_{\text {isotope }}$ & A $^{*} \mathbf{B}$ \\
\hline Pu238 & 0.03 & $2.63 \mathrm{E}+02$ & 0.079 \\
\hline Pu239 & 93.26 & $1.00 \mathrm{E}+00$ & 0.933 \\
\hline Pu240 & 5.98 & $3.70 \mathrm{E}+00$ & 0.221 \\
\hline Pu241 & 0.14 & $3.30 \mathrm{E}+01$ & 0.046 \\
\hline Pu242 & 0.04 & $6.03 \mathrm{E}-02$ & 0.000 \\
\hline Am241 & 0.45 & $5.70 \mathrm{E}+01$ & 0.257 \\
\cline { 2 - 4 } & Total & $\mathbf{1 . 5 3 5}$ \\
\hline
\end{tabular}

For a plutonium isotopic mixture that is predominantly elemental Plutonium, the plutonium isotopic mix is qualitatively similar to the hazards and would behave the same as 30-yr-old composition of weapons grade plutonium. The absorption rate, airborne release fraction (ARF) and airborne respirable fraction (RF) of ingrowth material will follow that of the host material. Since Am241 results from the decay of Pu241, Am241 will be in the plutonium matrix and exhibit the same release properties as plutonium, the ARF and RF for Plutonium are used for Americium. 


\subsection{References}

1. LA-12846-MS, Specific Activities and DOE-STD-1027-92 Hazard Category 2 Thresholds LANL Fact Sheet, Los Alamos National Laboratory, November 1994.

2. DOE/EH - 0071, Internal Dose Conversion Factors for Calculation of Dose to the Public, US Department of Energy, July 1988.

3. Facility Safety Plan - Building 332, Lawrence Livermore National Laboratory, July 2009. 


\section{Plutonium 239 Equivalency (PuE) Calculation Datasheet}

Datasheet to calculate the PuE, grams based on weapons grade plutonium material mass and isotopics. Follow instructions below.

Instructions:

Column A: Enter isotopic weight \% for each isotope from the material isotopic datasheet

Column B: Enter the total plutonium mass of the material

Column C: Calculate the isotopic mass by multiplying columns $A$ and $B$

Column D: Isotopic conversion factors are given.

Column E: Calculate isotopic PuE by multiplying columns C and D-

PuE, total: Calculate total PuE, grams by summing column $E$

\begin{tabular}{|c|c|c|c|c|c|}
\hline & A & B & $\begin{array}{c}C=A^{*} B \\
\text { (Equation 2) }\end{array}$ & D & $\begin{array}{c}E=C^{*} D \\
\text { (Equation1) }\end{array}$ \\
\hline Isotope & $\begin{array}{l}\text { Isotopic } \\
\text { weight \% }\end{array}$ & $\begin{array}{c}\text { Total Pu Mass, } \\
\text { grams }\end{array}$ & $\begin{array}{l}\text { Isotopic Mass, } \\
\text { grams }\end{array}$ & $\mathrm{CF}_{\text {isotope }}$ & $\begin{array}{l}\text { PuE, } \\
\text { grams }\end{array}$ \\
\hline Pu238 & & & & $2.63 \mathrm{E}+02$ & \\
\hline Pu239 & & & & $1.00 \mathrm{E}+00$ & \\
\hline Pu240 & & & & $3.70 \mathrm{E}+00$ & \\
\hline Pu241 & & & & $3.30 \mathrm{E}+01$ & \\
\hline Pu242 & & & & $6.03 \mathrm{E}-02$ & \\
\hline Am241 & & & & $5.70 \mathrm{E}+01$ & \\
\hline
\end{tabular}

Equation 1, PuE (CF, isotope)

$\mathrm{PuE}=\sum_{\mathbf{0}}^{\mathrm{n}}(\mathbf{M}$, isotope $\cdot \mathbf{C F}$, isotope $)$

$\mathrm{M}$, isotope $=$ Isotopic Mass (grams)

$\mathrm{CF}$, isotope $=$ Isotopic Conversion Factor

Equation 2, M,isotope

$\mathbf{M}$, isotope $=\mathbf{M}$, total $\cdot$ Isotope weight $\%$

$\mathrm{M}$, total $=$ Plutonium mass 